\title{
Nematode and Insect Management in Transitional Agricultural Systems
}

\author{
R. McSorley
}

Additional IndeX wORDs. agroecosystem design, cropping systems, integrated pest management, organic agriculture, sustainable agriculture

Summary. As an agroecosystem makes the transition from conventional to organic practices, changes in the pest management tactics used are often apparent. Despite varying degrees of efficacy among tactics, the issue of whether or not numbers of insect and nematode pests and their damage will become more severe in an organic system depends on the specifics of the pests and crops involved. Although many conventional systems rely on reactive strategies to deal with pest problems, an alternative approach is to redesign systems so that plant health is maximized, regardless of pest numbers, although this approach takes planning and time. An abrupt transition from conventional to organic may be risky if pest numbers are high and alternative practices are not yet in place. Hybrid systems, involving decreasing levels of conventional tactics and increasing levels of organic tactics, may be needed before the transitional period begins, in order to bridge the gap and lessen the impact of crop losses during the transitional period. The design of cropping systems with minimal pest impact requires a much more extensive and specific knowledge base than needed for reactive strategies.

s the transition from conventional to organic production oc-
curs, the management of insect and nematode crop pests can
pose particular difficulties. An obvious difference between conventional and organic production systems in the United States is in the use of synthetic chemical pesticides, but important changes in pest management strategies and philosophy occur as well.

\section{Changing pest management tactics}

Chemical control options available to organic producers are limited to certain organically-derived materials and natural products. However, a wide variety of nonchemical alternatives are available, which vary in their efficacy and frequency of use against insects or nematodes (Table 1). The relative rankings of efficacy or utility (Table 1) are arbitrary, but reflect the particular importance of the host-parasite relationship and crop sequences in managing plant-parasitic nematodes (McSorley, 1998) and the particular importance of manipulating natural enemies for insect pest management (Altieri, 1994; Letourneau, 1997; Smith and McSorley, 2000). In addition to some of the more commonly used methods (Table 1), a number of other options are applicable in various situations, including use of tillage, sanitation, trap crops, various physical factors (heat, flooding), and other methods (Landis, 2000; Letourneau, 1997; McSorley, 1998; Powers and McSorley, 2000; Romoser and Stoffolano, 1998).

Department of Entomology and Nematology, University of Florida, P.O. Box 110620, Gainesville, FL 32611-0620.

This work was supported by the Florida Agricultural Experiment Station, and approved for publication as journal series R-08225 
While these alternative practices are useful in many situations, reductions in pest numbers achieved may not be as rapid or drastic as those achieved with chemical pesticides. For example, numbers of plant-feeding insects are often lower in intercropped systems than in monoculture (Andow, 1991), but could be reduced to extremely low levels following insecticide application. Reductions in rootknot nematode (Meloidogyne incognita) damage following soil solarization were not as great as those obtained by soil fumigation with methyl bromide (Overman and Jones, 1986). Yields of a fall tomato (Lycopersicon esculentum) crop were similar following solarization or methyl bromide fumigation, but yield of doublecropped tomato in the following spring in methyl-bromide-treated plots was nearly three times that in solarized plots (Overman and Jones, 1986). In some situations, however, less pest mortality and reduced yield may be tolerated and profitable if treatment costs are lower and if a premium price is obtained for an organically grown product.

\section{Changing pest management strategies}

Although spectacular short-term reductions may be achieved through the use of pesticides, pest populations will recover over time. The resurgence of stubby-root nematodes (Paratrichodorusspp.) following soil fumigation (Weingartner et al., 1983) or the emergence of leafminers (Liriomyza spp.) as pests following insecticidal spray programs (Schuster et al., 1996) are two well-known examples of pest populations reaching higher levels following conventional pesticide practices. Over time, pest populations in some conventional sites may stabilize at higher levels than those present in some organic production sites.

Recent data on root-knot nematodes in vegetable production systems illustrate the fact that nematode population levels are not necessarily higher in organic systems, despite the lack of availability of chemical nematicides (Table 2). Thus, in a fumigated site such as Immokalee, nematode population levels in plots fumigated preplant with methyl bromide recovered by the end of the tomato season, although much higher levels were reached in nonfumigated plots (Table 2). Nema- tode populations in sites that did not receive any fumigation treatments stalower (Pine Island) levels than the 267 nemas/100 $\mathrm{cm}^{3}$ (43.8 nemas/inch ${ }^{3}$ ) soil reached in methyl bromide-treated plots in Immokalee, Fla. (Table 2). The Pine Island location was an organic site that involved a number of different treatments, one of which included use of a resistant tomato cultivar that lowered root-knot nematodes levels below detection (McSorley et al., 1999).

While chemical pesticides may provide quick reductions in pest populations, once the applications cease and provided that the crop is still available, pest populations have a natural tendency to increase to whatever carrying capacity the host crop will support (Powers and McSorley, 2000). Future treatments are required to keep pest populations suppressed, and the pest management strategy is essentially reactive.

An alternative strategy for pest management may be to design systems in which the carrying capacity or equilibrium level of the pest population is reduced (Altieri, 1987; Powers and McSorley, 2000). For instance, the carrying capacity of a pest species in the presence of natural enemies is likely lower than that in a system in which natural enemies are absent (Altieri, 1994; Bird and Berney, 1998). For example, populations of mite pests (Acarina) on fruit crops stabilize at much lower levels when predators are present than in intensively sprayed orchards where predators are reduced or absent (Croft and Hoyt, 1983; Zalom, 1997). Up to $90 \%$ of leafminers were parasitized in nonsprayed tomato fields

Table 1. Alternative practices useful in managing insect or nematode pests.

\begin{tabular}{lcc}
\hline \multirow{2}{*}{$\begin{array}{l}\text { Management } \\
\text { practice }\end{array}$} & \multicolumn{2}{c}{ Efficacy against } \\
\cline { 2 - 3 } Resistant cultivars & $++{ }^{\mathrm{z}}$ & Nematodes \\
Rotation crops & + & +++ \\
Cover crops & +++ & +++ \\
Releasing predators / parasites & +++ & +++ \\
Enhancing natural enemies & +++ & 0 \\
Optimizing field borders & +++ & + \\
Soil solarization & + & +++ \\
Intercropping & +++ & 0 \\
Destruction of weed hosts & + & +++ \\
Organic amendments & 0 & + \\
Optimizing planting date & + & + \\
Improved crop tolerance & + & + \\
\hline
\end{tabular}

${ }^{\mathrm{z}} 0=$ limited use or ineffective $;(+)=$ effective in some specific cases $;(+++)=$ applicable in many cases.

in Florida, but leafminers can become an important secondary pest if the parasitoid wasps (Hymenoptera) that provide biological control are reduced by indiscriminate insecticide use (Schuster etal., 1996). Nematode pests may also stabilize to lower equilibrium levels when natural enemies are maintained (Kerry, 1987; Stirling, 1991). Over a 14-year monoculture of nematode-susceptible cereals in the United Kingdom, populations levels of the cereal cyst nematode (Heterodera avenae) were high [15 to $70 \mathrm{eggs} / \mathrm{g}$ (425 to 1,985 eggs/oz) soil during the first 4 years, fell to 10 eggs $/ \mathrm{g}$ (284 eggs/oz) in the fifth year, and to levels below $10 \mathrm{eggs} / \mathrm{g}$ with a continuing slow decline in following years (Gair et al., 1969). Decline was attributed to buildup of fungal antagonists over time (Kerry, 1987). By using several alternative pest management practices, it may be possible to design systems in which pests are prevented from reaching high levels (Altieri, 1987; Luna and House, 1990; Powers and McSorley, 2000). This strategy of agroecosystem design is particularly applicable to organic systems, for which reactive tactics may be lacking.

\section{Limitations in making transitions}

An abrupt transition from an intensive pesticide program to an organic system could be difficult. Many of the tactics used in alternative systems require some time for development and may not have much initial impact against high pest populations present following a conventional system (natural enemies not yet in place, etc.). In one site to which a mulch of yard waste compost was added to bilized at higher (Alachua County) or 
Table 2. Population levels of the root-knot nematode (Meloidogne incognita) following susceptible vegetable crops, ${ }^{\mathrm{Z}}$ preceded by various management options.

\begin{tabular}{|c|c|c|c|c|c|}
\hline Location & Season & Crop & $\begin{array}{l}\text { Management } \\
\text { conditions }^{y}\end{array}$ & $\begin{array}{l}\text { Nematodes/ } \\
100 \mathrm{~cm}^{3} \text { soil }\end{array}$ & Reference \\
\hline Immokalee, Fla. & 1996 & Tomato & $\begin{array}{l}\text { Preplant fumigated with methyl bromide } \\
\text { Not fumigated }\end{array}$ & $\begin{array}{r}267 b^{x} \\
1242 a\end{array}$ & McSorley et al., 1997 \\
\hline Alachua Co., Fla. & 1994 & Squash & $\begin{array}{l}\text { Transplanted, yard waste compost } \\
\text { Transplanted, no compost }\end{array}$ & $\begin{array}{r}416 \mathrm{a} \\
460 \mathrm{a}\end{array}$ & McSorley, and Gallaher, 1995 \\
\hline Pine Island, Fla. & 1997-98 & Tomato & $\begin{array}{l}\text { Cowpea cover crop, then pepper crop } \\
\text { Solarization, then pepper crop } \\
\text { Weeds, then pepper crop } \\
\text { Marigold (Tagetes minuta) cover crop, } \\
\text { then pepper crop } \\
\text { Pepper crop, then resistant tomato }\end{array}$ & $\begin{array}{r}230 \mathrm{a} \\
59 \mathrm{a} \\
105 \mathrm{a} \\
124 \mathrm{a} \\
0 \mathrm{a}\end{array}$ & McSorley et al., 1999 \\
\hline
\end{tabular}

${ }^{z}$ Scientific names: tomato $=$ Lycopersicon esculentum, squash $=$ Cucurbita pepo, cowpea $=$ Vigna unguiculata, pepper $=$ Capsicum annumm, marigold $=$ Tagetes minuta.

yo nematicides were used at these sites, except as noted.

${ }^{x}$ Nematode population density at final harvest of crop indicated. Means in column for each location followed by the same letter do not differ $(P \leq 0.05)$ according to Duncan's multiple-range test.

${ }^{\mathrm{w}}$ Cropping sequence at this organic site involved a summer cover crop or solarization, a fall crop of pepper, and a spring crop of susceptible (or resistant) tomato.

modify the soil environment, population levels of root-knot nematodes reached 707 nemas $/ 100 \mathrm{~cm}^{3}$ (115.9 nemas / inch ${ }^{3}$ ) soil during the first year after application, but only 55 and 72 nemas $/ 100 \mathrm{~cm}^{3}$ (9.0 and 11.8 nemas $/$ inch $^{3}$ ) soil in the second and third years respectively (McSorley and Gallaher, 1996). In the cereal cyst nematode example mentioned previously, crop yields were poor during the first 4 years of the long monoculture, reached levels that were half of the yields achieved by crop rotation during years 4 to 8 , and improved after 9 to 10 years (Gair et al., 1969). Kerry (1987) recognized a delay, or induction period, while biological control agents built up, followed by a suppressive phase in subsequent years, when populations of antagonists were sufficient to maintain the target pest at low levels. The length of time needed to stabilize unusually high pest populations depends on the system, but a producer may be unwilling to tolerate several seasons of very heavy pest pressure and poor yields while making the transition.

Instead, it may be preferable to make preliminary preparations over several seasons, even before the transition period to organic certification begins, phasing out intensive chemical practices while phasing in alternative practices. The use of some chemical pesticides during this period will delay the certification process, but may provide an opportunity to manage the extreme pest populations that may be present following conventional practices. During this period, intensively sprayed insecticides could be replaced by less frequent sprays, lower rates, and materials less toxic to natural enemies (Stary and Pike, 1999). The integrated pest management (IPM) approach of scouting and treatment on demand is applicable to organic systems. However, some IPM programs are essentially pesticide management programs (Luna and House, 1990). As such, they may not be valid organic tactics, but may help to bridge the gap to the early stages of transition. In the meantime, some organic tactics could be incorporated, such as manipulation of field borders to encourage natural enemies, an approach that has been used successfully in California (Nicholls et al., 2000) and Germany (El Titi and Landes, 1990). As the agroecosystem is gradually redesigned, a variety of practices may be used to augment natural enemies and to increase plant diversity in the system and in the landscape (Altieri and Nicholls, 1999; Letourneau, 1997; Luna and House, 1990; Stary and Pike, 1999), and then the transition to organic certification can proceed.

Alternative chemicals might be used before making a transition from nematode management by methyl bromide, and solarization may be useful during the transition period. The combination or integration of several nonchemical tactics such as use of cover crops, rotation, resistant cultivars, or organic amendments may be required for nematode management in organic systems (McSorley, 1998). The use of organic amendments in nematode management is particularly problematic. In the long term, organic amendments may stimulate nematode antagonists (Kerry, 1987), but the improved crop fertility and growth due to organic amendments may stimulate plant-parasitic nematodes as well (McSorley et al., 1997). In this regard, it is important to recognize that crop performance, not dead nematodes, is the ultimate goal of most producers. In one instance, nematode numbers in an Alachua Co., Fla. site were similar in plots amended with yard-waste compost and in nonamended plots (Table 2 ). However, yields of yellow squash (Cucurbita pepo) in amended plots were $45.6 \%$ greater than the state average while those in nonamended plots were $37.6 \%$ lower than the state average for that year (McSorley and Gallaher, 1995). Despite the presence of high numbers of root-knot nematodes, the organic amendment improved crop performance, soil fertility, organic matter, and water-holding capacity. Improving crop tolerance to nematodes may be useful in organic systems and especially in systems in which natural enemies have not had sufficient time to build up.

The greatest limitation in making the transition from conventional to organic systems is the relative lack of information about designing agroecosystems with minimal pest impact. Relatively little information may be required for using a reactive, conventional strategy. In contrast, detailed, specific information on pest biology and ecology for a particular production system is required to redesign an agroecosystem for optimum pest management using alternative methods. Luna and House (1990) conceptualized the transitional phase as involving decreases in material inputs (pesticide, fuel, fertilizer) with increases in information inputs (biological control, crop 
and soil ecology). The specific information required for effective pest management may be lacking in many cases. In addition, the utility of basic pest management practices and principles varies depending on the specific system involved. Thus, in reviewing studies that compared insect management in polyculture and monoculture, Andow (1991) noted that $52.7 \%$ of natural enemies were higher in polyculture as expected, but for $9.3 \%$ of natural enemies, the reverse occurred. This example underscores the need for specific information just to determine whether a particular principle may apply or not; even more information would be required to understand how to apply principles to specific situations. This knowledge must be obtained from new research studies and site-specific tests.

\section{Literature cited}

Altieri, M.A. 1987.Agroecology. Westview Press, Boulder, Colo.

Altieri, M.A. 1994. Biodiversity and pest management in agroecosystems. Food Products Press, New York.

Altieri, M.A. and C.I. Nicholls. 1999. Biodiversity, ecosystem function, and insect pest management in agricultural systems, p. 69-84. In:W.W. Collins and C.O. Qualset (eds.). Biodiversity in agro-ecosystems. CRC Press, Boca Raton, Fla.

Andow, D.A. 1991. Vegetational diversity and arthropod population response. Annu. Rev. Entomol. 36:561-586.

Bird, G.W. and M.F. Berney. 1998. Pest ecology and management, p. 54-58. In: M.A. Cavigelli, S.R. Deming, L.K. Probyn, and R.R. Harwood (eds.). Michigan field crop ecology. Mich. State Univ. Ext. Bul. E-2646.

Croft, B.A. and S.C. Hoyt (eds.). 1983. Integrated management of insect pests of pome and stone fruits. Wiley, New York.
El Titi, A. and H. Landes. 1990. Integrated farming system of Lautenbach: A practical contribution toward sustainable agriculture in Europe, p. 265-286. In: C.A. Edwards, R. Lal, P. Madden, R.H. Miller, and G. House (eds.). Sustainable agricultural systems. St. Lucie Press, Delray Beach, Fla.

Gair, R., P.L. Mathias, and P.N. Harvey. 1969. Studies of cereal nematode populations and cereal yields under continuous or intensive culture. Ann. Appl. Biol. 63:503512 .

Kerry, B.R. 1987. Biological control, p. 233-263. In: R.H. Brown and B.R. Kerry (eds.). Principles and practice of nematode control in crops. Academic Press, Sydney.

Landis, D.A. 2000. Insect pest ecology and management, p. 35-50. In: M.A. Cavigelli, S.R. Deming, L.K. Probyn, and D.R. Mutch (eds.). Michigan field crop pest ecology and managment. Mich. State Univ. Ext. Bul. E-2704.

Letourneau, D.K. 1997. Plant-arthropod interactions in agroecosystems, p. 239290. In: L.E. Jackson (ed.). Ecology in agriculture. Academic Press, San Diego, Calif.

Luna, J.M. and G.J. House. 1990. Pest management in sustainable agricultural systems, p. 157-173. In: C.A. Edwards, R. Lal, P. Madden, R.H. Miller, and G. House (eds.). Sustainable agricultural systems. St. Lucie Press, Delray Beach, Fla.

McSorley, R. 1998. Alternative practices for managing plant-parasitic nematodes. Amer. J. Alt. Agr. 13(3):98-104.

McSorley, R. and R.N. Gallaher. 1995. Cultural practices improve crop tolerance to nematodes. Nematropica 25(1):53-60.

McSorley, R. and R.N. Gallaher. 1996. Effect of yard waste compost on nematode densities and maize yield. Suppl. J. Nematol. 28(4S):655-660.

McSorley, R., M. Ozores-Hampton, P.A. Stansly, and J.M. Conner. 1999. Nematode management, soil fertility, and yield in organic vegetable production. Nematropica 29(2):205-213.
McSorley, R., P.A. Stansly, J.W. Noling, T.A. Obreza, and J.M. Conner. 1997. Impact of organic soil amendments and fumigation on plant-parasitic nematodes in a southwest Florida vegetable field. Nematropica 27(2):181-189.

Nicholls, C., M. Parrella, and M.A. Altieri. 2000. Establishing a plant corridor to enhance beneficial insect biodiversity in an organic vineyard. Org. Farming Res. Found. Info. Bul. 7:7-9.

Overman, A.J. and J.P. Jones. 1986. Soil solarization, reaction, and fumigant effects on double-cropped tomato under full-bed mulch. Proc. Fla. State Hort. Soc. 99:315318.

Powers, L.E. and R. McSorley. 2000. Ecological principles of agriculture. Delmar Thomson Learning, Albany, N.Y.

Romoser, W.S. and J.G. Stoffolano, Jr. 1998. The science of entomology, $4^{\text {th }}$ ed. WCB/McGraw-Hill, Boston.

Schuster, D.J., J.E. Funderburk, and P.A. Stansly. 1996. IPM in tomatoes, p. 387411. In: D. Rosen, F.D. Bennett, and J.L. Capinera (eds.). Pest management in the subtropics. Intercept, Andover, U.K.

Smith, H.A. and R. McSorley. 2000. Intercropping and pest management: A review of major concepts. Amer. Entomol. 46(3):152-161.

Stary, P. and K.S. Pike. 1999. Uses of beneficial insect diversity in agroecosystsem management, p. 49-67. In: W.W. Collins and C.O. Qualset (eds.). Biodiversity in agroecosystems. CRC Press, Boca Raton, Fla.

Stirling, G.R. 1991. Biological control of plant parasitic nematodes. CAB Intl., Wallingford, U.K.

Weingartner, D.P., J.R. Shumaker, and G.C. Smart, Jr. 1983. Why soil fumigation fails to control potato corky ringspot disease. Plant Dis. 67(2):130-134.

Zalom, F.G. 1997. IPM practices for reducing insecticide use in U.S. fruit crops, p. 317-342. In: D. Pimentel (ed.). Techniques for reducing pesticide use. Wiley, New York. 